\section{Women, Knowledge and Reality: Explorations in Feminist Philosophy}

Edited by Ann Garry and Marilyn Pearsall

Unwin Hyman: Boston 1989

ISBN 0044452225 Pbk 111.95

This rich collection of papers on knowledge and reality has been assembled primarily for feminist teachers and students of philosophy. To a non-philosopher the organization of the chapters paralleling the traditional questions of mainstream philosophy sits uneasily with the inter- (or what I take to be the anti-) disciplinary strategies of much feminist theorizing. Of twenty-one authors, only four are not professional philosophers; this choice, which is assuredly not by chance, both reflects the growing strength of feminists in the subject and also indicates the specificity of the challenge being made to mainstream philosophy. It is strongly USA based, with only two non-US-based contributors. This is a pity, especially in a book being brought out in Britain among other countries, where the discussions within the very lively Women and Philosophy Group suggests that their departments are still pretty much unreconstructed. The benefits of the strategy of prioritizing philosophers carries some teaching costs, notably there is no unequivocal statement of standpoint theory, as, apart from early Sandra Harding (1983), not the later paper included here, the most usually cited proponents are not philosophers but the political theorist Nancy Hartsock (1983), or sociologists such as Dorothy Smith (1987) or Hilary Rose (1983). Arguably, other contributors share the stance, but this is the one obvious gap in an otherwise wellchosen and balanced collection.

Thus, although there are overlaps, it is not meaningful to contrast this collection with, for example, the pioneering collection of Sandra
Harding and Merrill Hintikka Discovering Reality (1983), or the papers from Signs, Feminist Inquiry, edited by Jean O'Barr and Sandra Harding (1987), or the recent thematic collection Gender/Body/Knowledge edited by Alison Jagger and Susan Bordo (1989). These collections are pursuing problems first and are no respecters of disciplinary boundaries.

That said, it is entirely possible to skip the detailed links to philosophy and still enjoy the collective coherence of the selection. Questions about the production of knowledge, whether feminist truth-claims about the nature of reality are, or could be, better/truer than those of androcentric knowledge, or whether, as we learn to take language seriously, truth-claims themselves fly out of the postmodernist window, have become a focus of feminist theorizing over the last decade. Doing, and or reading, what we now see claimed as philosophy, is far too interesting and too important to be left solely to one professional grouping. Reading the collection was for me a mixture of recognizing and remembering just how good were particular classics and how pleased I was for them to be in one accessible place not least for teaching - such as Janice Moulton's 'The Myth of the Neutral Man' (1977) or Genevieve Lloyd's 'The Man of Reason'(1979), and being challenged and excited by recent papers such as Jeffner Allen's powerfully written 'Women Who Begat Women Must Thwart Major Sophisms' (1988), which seeks to move feminism beyond the postmodernism/modernism debate. By contrast Andreas Nye's (1989) discussion of French feminism's contribution to the philosophy of language seemed more like an elegant exigesis of that which Allen was seeking to use as both a resource and to surpass. In this review I try to indicate the original publication date of the chapters, as those familiar with the work of particular theorists and the development of particular debates will know that people's 
minds and issues change - yet want to pick up a picture of the whole book.

For anyone entering higher education as a whole and philosophy in particular, Janice Moulton's (1983) critique of the adversary paradigm is a must, and exactly the right chapter to open with. It empowers students and their teachers offering a different vision of the work of doing theory. It re-sets the stage. Elizabeth Spellman's (1983) chapter on 'Anger and Insubordination' is another must for beginners and a helpful reminder for jaded others on the appropriateness of anger and other emotions in thinking. If we follow Marilyn Frye's metaphor in which women are the invisible stagehands, and men the players in a tale of phallocentric reality, seeing the stage-setters is crucial. In 'To See and be Seen' (1983), Frye gently and playfully dissects 'reality' and reminds us of its roots in 'regal', so that only that which the king sees and counts is real. Affirming her own lesbianism, she observes that lesbians are unseen and uncounted and thence outside reality. Following Sarah Hoagland's pioneering claim that lesbian feminists enjoy an exceptional epistemic position, she suggests that while it is true that all kinds and colours of women are erased by masculinist reality, the exclusion of lesbians is different and is related to 'unusual knowing'. As a woman loving women, denied both existence and authority, the lesbian feminist is consciously outside the phallocentric construction. Frye is clear-eyed about the chances of one dissident cracking the conceptual consensus, but hints of the dangerous contagion that loyalists have to fear. In her metaphysic, lesbians are women seers.

While it is impossible for reasons of space to be even-handed to all the authors, some inevitably speak more strongly to particular theoretical and personal concerns of the reviewer. For me, Judith Butler's chapter examining the contribution of de Beauvoir to philosophy is a gem. She shows how de Beauvoir, like Sartre and Merleau-Ponty, is concerned with the structures of lived experience, especially the structures of embodiment. While they focus on the visual universal body, de Beauvoir asks how is it that the body takes on a gendered form? Butler then points with apparent simplicity to the distinction between 'One is not born a woman but becomes one' and 'One is not born a woman but is made one'. The power of de Beauvoir's 'become' as a transitive verb, resolves issues of agency and structure and denaturalizes the body itself. Perhaps because, while reading this book, I too have been trying to come to terms with the death of my mother, the reminder that for de Beauvoir contemplating the death of her mother - not least as a dress rehearsal for herself - death itself is understood as far from natural, made special sense. For de Beauvoir, death was 'a perpetual and an offence, in that the body is deprived of its project, denied its becoming'. Death, even though it is inevitable, and even where it is accepted, is thus always a violation.

The attempt by feminists to overcome the division between cognition and affect, between knowledge and love is a constant theme. Maria Lugones' (1987) scrupulous self-examination of what she speaks of as her arrogance towards her mother, and her experience of arrogance as a woman of colour, returns to the issue of love, knowledge and the politics of reality. She is not concerned to apportion blame but to find what she describes as a loving way out of it. Without love from other women, not least from white Anglo women, whom she is frequently among, she sees women of colour as insubstantial, as lacking reality. Her chapter importantly complements and builds from Frye's. Alison Jaggar's (1989) chapter also seeks to examine emotion, not least that most complex feeling of love, and re-vision 
it with in a feminist epistemology in which emotion is neither more basic than reason, observation or action, nor secondary to them. This paper is an interesting move on Jaggar's part towards the more reflexive accounts of the postmodernists without relinquishing her realist truth-claims.

One of the few papers by a nonphilosopher which holds firmly onto the privileged truth-claims of the natural sciences is Evelyn Keller's widely published (1982) Signs essay. This early exploration of the price science pays for that division of labour in which objectivity is cast as male and subjectivity as female, resists relativism which would only sustain the old dichotomy of feminine subjectivity and masculine objectivity. For Keller, the way out of the domination of science is through a science which transcends the dichotomy. She suggests that, within the history of science, such alternative voices have had a continuous if subordinated presence, as exemplified by the work of the geneticist and nonfeminist Barbara McClintock. Helen Longino (1987) by contrast sees a feminist natural science as something out there and, echoing an earlier analysis by the historian of science Liz Fee, not possible within the contemporary profit-oriented and militaristic society.

Sandra Harding's paper examines the strategies of justification, that is, the different epistemologies implicitly or explicitly held by feminists making knowledge claims. First surveying the strengths and weaknesses of 'feminist empiricism', and genially inviting us to enjoy the heresy of the category, she critically discusses standpoint theory although still favourably surveying its potentiality through an examination of Dorothy Smith's work. But the power of the new scepticism that the mind - even the feminist mind is a glassy mirror which can reflect reality, has influenced practically everyone working in the social studies of science, not least Harding.
In consequence, she suggests that perhaps our accounts are better understood as a sea of representations. She quotes Jane Flax, who shifted from something close to standpoint theory to postmodernism, saying that perhaps there can only be 'one reality' from the falsely universalizing perspective of the master. But Harding's chapter is especially precious for her sense of the historical context of our debates, her sense of the extraordinary times in which we find ourselves in which 'no traditional assumptions are immune from reasonable criticism', and for her optimism that feminist postmodernism has also a 'positive' programme in that it wants to produce less distorting accounts of nature and social relations. It can be understood as arguing that the standpoint theorists simply haven't yet gone far enough. Certainly something like this comes very strongly from reading Donna Haraway's wonderful Primate Visions published, (or one might say privished by the outrageous price of $£ 40$ set by its publishers) also in 1989.

At $£ 11.95$, pricy for students and other hard-up feminists, but well produced and a good, if at times, tough read.

\section{Hilary Rose}

\section{References}

haRAWAY, Donna (1989) Primate Visions: Gender, Race and Nature in the World of Modern Science, New York and London: Routledge.

HARDING, Sandra (1983) 'Why has the Sex/ Gender System become visible only now' in HARDING and HINTIKKA, pp. 311-24.

HARDING, Sandra and HINTIKKA, Merril (1983) editors, Discovering Reality, Dordrecht: Reidel.

HARDING, Sandra and O'BARR, Jean (1987) editors, Feminist Inquiry, Chicago: Chicago University Press.

HARTSOCK, Nancy (1983) "The Feminist Standpoint; Developing the ground for a specifically feminist historical materialism', in HARDING and HINTIKKA, pp. 283-310. 
JAGGER, Alison and BoRDo, Susan (1989) editors, Gender, Body, Knowledge: Feminist Reconstructions of Being and Knowing, New Brunswick: Rutgers University Press.

ROSE, Hilary (1983) 'Hand, Brain and
Heart: Towards a Feminist Epistemology for the Natural Sciences' in HARD. ING and O'BARR.

SMITH, Dorothy (1987) The Everyday World as Problematic: a Feminist Sociology, Milton Keynes: Open University Press.

\section{Texts, Facts and Femininity: Exploring the Relations of Ruling}

Dorothy E. Smith

Routledge: London 1990

ISBN 0415032318 Hbk £30.00

I first encountered Dorothy Smith's work in a piece in the Socialist Register (Miliband and Saville, 1983) that refreshingly challenged monogendered Marxist accounts of class and family; then again representing the 'feminist standpoint' approach in The Everyday World as Problematic. In this collection of essays, dating back to the late $1970 \mathrm{~s}$, and her famous piece ' $\mathrm{K}$ is Mentally Ill', Smith sets out her main preoccupations as a feminist sociologist. The terms in the title could equally be 'discourse, practice and feminism'. First, she stresses the importance of ethnomethodology and discourse theory for understanding contemporary power relations. But second, she retains a broadly Marxist understanding of the materiality of texts and of the social practices within which they are situated. She remains enough of a realist to insist that there is a world which defines itself independently of our inquiry. And third, it is feminism which provides the vantage-point for her critique of mainstream sociology and her critical usage of both Marxism and discourse theory.

Sociological discourse, she argues, with its emphasis on rationality, objectivity and scientificity, is deeply implicated in the relations of ruling. Her counter to this is to explore the social from the standpoint of women's experience. She is not referring here to a particular kind of knowledge so much as a discursive strategy wherein the speaker lays claim to authority in speaking of her everyday life. This is 'insiders' sociology'. Throughout the text 'the sociologist' is referred to as 'she', reminding us continuously that sociology is always written from within particular standpoints. 'Social reality', she reminds us, is not external to she who experiences, makes, or observes it' (p.53). Sociology retains a geocentric cosmology, treating the world as fixed when we have to shift to a heliocentric cosmology. It is only when the observer finds 'herself' moving in relation to what 'she' observes that there is scope for an 'accurate' account of the (solar) system.

Sociology, for Smith, has been naive about texts, continuing to treat them as a source of information about something else, rather than as phenomena in their own right which actively structure social and power relations. The key characteristic of modernity, she says, is that social relations are mediated by texts; discourses are embedded in the sets of everyday and institutional contexts in which subjects act. Marxists must accept that textual analysis has now become crucial for understanding the ubiquitous and generalizing organization of the ruling relations. She stresses the emergence of 'public, textually mediated discourse as a new form of social relation transcending and organising local settings' (p. 167).

Smith credits ethnomethodology, Garfinkel in particular, with discovering the text as a significant constituent of social relations, and Foucault with developing these earlier insights. Discourse theorists dis- 